\title{
Pendapatan Usahatani Kelapa Sawit Pasca Umur Produktif Di Desa Bukit Makmur Kecamatan Sungai Bahar Kabupaten Muaro Jambi
}

\author{
${ }^{*}$ Nida Kemala, ${ }^{1}$ Wiwin Alawiyah dan ${ }^{2}$ Prasetyo Yuanwiarno \\ ${ }^{1}$ Dosen Program Studi Agribisnis, Fakultas Pertanian Universitas Batanghari \\ ${ }^{2}$ Alumni Program Studi Agribisnis, Fakultas Pertanian Universitas Batanghari \\ Jl. Slamet Riyadi, broni Jambi. 36122. Telp. +6274160103 \\ ${ }^{* 1}$ e-mail korespondensi : nida.kemala@ unbari.ac.id
}

\begin{abstract}
This research was conducted in Bukit Makmur Village, Sungai Bahar Sub-District, Muaro Jambi Regency. The location was selected purposively based on that village has the largest number of farmers with post productive oil palm trees among the villages in the sub-district. The research took place since mei 2020. The research aimed was to find out the descriptions of the business activities of post productive oil palm farming, its farmer income. The number of sampels taken in the research were 41 famers which taken by simple random sampling method. To know the description of post productive oil palm farming activity in the research area was analized by descriptive analysis. The results showed that the average area of land owned by farmers was 3.54 hectares with the status of private ownership and the majority of oil palm plants were 28.85 years on average. The average production of oil palm farming was 2,908 kg / Ha/ month. Revenues ranged from Rp. 1,015,8002,686,400 / Ha / Month with an average income of Rp. 1,311,417 / Ha / Month with a Production cost of Rp. 528,832 / Ha / Month. Meanwhile, the total income ranges from Rp. 300,913 - 2,189,206 / Ha / month with an average farmer income of Rp. 782,585 / Ha / Month.
\end{abstract}

Keywords : Income, Oil Palm, post productive

\begin{abstract}
Abstrak. Penelitian ini dilakukan di Desa Bukit Makmur, Kecamatan Sungai Bahar, Kabupaten Muaro Jambi. Lokasi ini dipilih secara sengaja karena desa ini memiliki petani kelapa sawit pasca umur produktif dengan jumlah terbanyak diantara desa lainnya di Kecamatan Sungai Bahar. Penelitian ini bertujuan untuk mengetahui gambaran usahatani kelapa sawit pasca umur produktif dan pendapatan yang diperoleh petani dari usahatani kelapa sawit pasca umur produktif. Jumlah sampel yang diambil dalam penelitian ini adalah 41 orang petani yang diilih secara acak (simple random sampling). Untuk mengetahui gambaran usahatani kelapa sawit pasca umur produktif di Desa Bukit Makmur dianalisis secara deskriptif. Hasil penelitian menunjukkan bahwa Rata-rata luas lahan yang dimiliki petani adalah 3,54 Ha dengan status milik pribadi dan mayoritas tanaman kelapa sawit sudah berumur tua rata - rata 28,85 tahun. Rata - rata produksi hasil usahatani kelapa sawit adalah $2.908 \mathrm{~kg} / \mathrm{Ha} / \mathrm{bulan}$.Penerimaan berkisar antara Rp.1.015.800-2.686.400/Ha/Bulan dengan rata-rata penerimaan sebesar Rp. 1.311.417/Ha/Bulan dengan biaya Produksi sebesar Rp. 528.832 /Ha/Bulan. Sedangkan total pendapatan berkisar antara Rp 300.913-2.189.206/Ha/Bulan dengan rata-rata pendapatan petani sebesar Rp. $782.585 / \mathrm{Ha} / \mathrm{Bulan}$.
\end{abstract}

Kata Kunci : Pendapatan, Kelapa Sawit, Pasca umur Produktif

\section{PENDAHULUAN}

Kelapa sawit merupakan salah satu komoditas utama disektor perkebunan dikarenakan kelapa sawit merupakan tanaman yang banyak memiliki produk turunan. Pengembangan perkebunan kelapa sawit merupakan salah satu carauntuk menciptakan lapangan kerja baru dan untuk meningkatkan pendapatan para petanikelapa sawit. Luas Areal Perkebunan Kelapa Sawit di Provinsi Jambi terus meningkat dari tahun 2013 -2017. Luas Lahan Kelapa Sawit di Kabupaten Muaro Jambi adalah 97.630 Ha atau sebesar 21,2\% dari total luas lahan kelapa sawit rakyat di Provinsi Jambi dan merupakan kabupaten yang mengusahakan kelapa sawit terluas di Provinsi Jambi. Produksi kelapa sawit Kabupaten Muaro Jambi pda tahun 2017 adalah sebesar 188.534 Ton (sebesar 18,59 \% dari total produksi kelapa sawit Provinsi Jambi). Produktivitas lahan kelapa sawit di Muaro Jambi pada tahun 2017 tergolong rendah. Hal ini dikarenakan luasnya areal tanaman tidak menghasilkan (TTM) atau tanaman rusak (TR) di Kabupaten tersebut yaitu sebesar 12.044 Ha atau sebesar 81,37\% dari total keseluruhan tanaman tidak menghasilkan (TTM) yang ada di Provinsi Jambi (Dinas Perkebunan Provinsi Jambi. 2017)

Luas lahan Kelapa Sawit di Kecamatan Sungai Bahar adalah 32.312 Ha dan merupakan lahan kelapa sawit terluas dan memiliki jumlah produksi tertinggi di Kabupaten Muaro Jambi. Jumlah Produksi Kelapa Sawit di Kecamatan Sungai Bahar mencapai 46.416 Ton atau 24,61\% dari total jumlah produksi yang ada di Kabupaten Muaro Jambi. Produktivitas usahatani kelapa sawit di Kecamatan Sungai Bahar masih rendah yaitu sebesar 2.388 Ton/Ha. Luasnya lahan Tanaman Tidak Menghasilkan (TTM)dan Tanaman Rusak (TR) yaitu sebesar 11.930 Ha sehingga menyebabkan rendahnya produktivitas lahan di Kecamatan Sungai Bahar.

Kecamatan sungai Bahar mulai mengusahakan tanaman kelapa sawit sejak tahun 1983, sehingga usia kelapa sawit sudah memasuki umur 33 tahun. Umur ekonomis kelapa sawit adalah 25 tahun. Semakin tua umur tanaman maka produktivitas tanaman tersebut semakin menurun sehingga pendapatan yang diperoleh petani akan menurun. Petani juga mengalami kesulitan pada saat panen tanaman tua dikarenakan tanaman yang terlalu tinggi sehingga efektivitas panen rendah dan menyebabkan biaya produksi meningkat. 
Desa Bukit Makmur merupakan salah satu desa yang memiliki luas lahan, jumlah petani, kelompok tani terbesar yang saat ini yang masih mengusahakan usahatani kelapasawit yang berusia 27 tahun pada tahun 2020. Dilihat dari usianya, produksi tanaman kelapa sawit tersebut sudah tidak produktif lagi, tentu saja berpengaruh terhadap pendapatan petani kelapa sawit, alasan petani masih bertahan dengan tanaman pasca produktif karena tingginya biaya untuk meremajakan sawit sehingga petani tidak secara menyeluruh meremajakan tanaman kelapa sawit.

Berkaitan dengan uraian diatas, maka penulis tertarik untuk mengetahui gambaranusahatani kelapa sawit pasca umur produktif dan pendapatan petani kelapa sawit pasca umur produktif di Desa Bukit Makmur Kecamatan Sungai Bahar Kabupaten Muaro Jambi`.

\section{METODOLOGI PENELITIAN}

Penelitian dilaksanakan di Desa Bukit Makmur Kecamatan Sungai Bahar Kabupaten Muaro Jambi yang merupakan desa yang masih melakukan kegiatan usahatani kelapa sawit pasca umur produktif namun sudah melewati masa produktifnya dan belum dilakukan peremajaan. Selain itu Desa Bukit Makmur merupakan salah satu desa yang memiliki luas lahan terluas dibandingkan desalainnya yaitu 1200 Ha (UPTD Kecamatan Sungai Bahar 2017.).

Penelitian ini menggunakan jenis data menurut waktu adalah data Cross Section dan data berdasarkan skala ukur adalah data rasio. Berdasarkan sumbernya meliputi data primer dan data sekunder. Data primer dalam penelitian ini diperoleh dari petani yang masih melakukan kegiatan usahatani kelapa sawit pasca umur produktif di daerah penelitian yang dikumpulkan secara langsung dengan cara observasi dan wawancara, sedangkan data sekunder dalam penelitian ini diperoleh dari laporan instansi-instansi yang berkaitan dengan penelitian, yaitu Dinas Perkebunan Provinsi Jambi, Dinas Kehutanan dan Perkebunan Muaro Jambi, UPTD Kecamatan Sungai Bahar dan literatur-literatur. Metode pengumpulan data yang digunakan adalah metode survey.

Populasi petani dalam penelitian ini ditentukan dengan menggunakan metode Slovin. Adapun rumus Slovin yaitu dengan ketentuan apabila populasi lebih dari 100 orang maka diambil presisi $15 \%-20 \%$, jika populasi berjumlah 51-100 orang maka presisi diambil $10 \%$ dan jika populasinya kurang dari 50 orang maka populasi diambil semua. Adapun rumus penarikan sampel adalah:

$n=\frac{n}{n d^{2}+1}$

Keterangan:

$\mathrm{N}=$ Jumlah sampel (Orang)

$\mathrm{N}=$ Jumlah populasi (Orang)

$\mathrm{d}^{2}=$ Tingkat presisi $(15 \%)$

Jumlah populasi di daerah penelitian adalah 600 orang petani yang melakukan usahatani kelapa sawit yang dalam kategori pasca umur produktif. Dari perhitungan sampel dengan tingkat presisi 15\%, maka diperoleh jumlah sampel sebanyak 41 orang petani. Teknik pengambilan sampel pada penelitian ini dilakukan dengan menggunakan metode acak sederhana (Simple Random Sampling).

Metode analisis yang digunakan dalam penelitian ini adalah analisis deskriptif dankuantitatif. Analisis deskriptif digunakan untuk mengetahui gambaran usahatani kelapa sawit pasca umur produktif. Analisis kuantitatif digunakan untuk mengetahui pendapatan usahatani kelapa sawit pasca umur produktif. Untuk menghitung pendapatan usahatani kelapa sawit pasca umur produktif (Soekartawi, 2002) yaitu,

\section{$\mathbf{P d}=\mathbf{T R}-\mathbf{T C}$}

Dimana :

$\mathrm{Pd}=$ Pendapatan Usahatani $(\mathrm{Rp} / \mathrm{Ha} / \mathrm{Bulan})$

$\mathrm{TR}=$ Total Penerimaan $(\mathrm{Rp} / \mathrm{Ha} /$ Bulan $)$

$\mathrm{TC}=$ Total Pengeluaran $(\mathrm{Rp} / \mathrm{Ha} /$ Bulan $)$

Untuk menghitung total penerimaan (TR) usahatani kelapa sawit Pasca UmurProduktif digunakan rumus (Soekartawi, 2002) yaitu,

\section{$\mathbf{T R}=\mathbf{Y} \cdot \mathbf{P y}$}

Dimana :

$\mathrm{Y}=$ Produksi (Kg/Ha/Bulan)

$\mathrm{Py}=$ Harga yang diterima $(\mathrm{Rp} / \mathrm{Kg})$ 
Nida Kemala, Wiwin Alawiyah dan Prasetyo Yuanwiarno. Pendapatan Usahatani Kelapa Sawit Pasca Umur Produktif di Desa Bukit Makmur Kecamatan Sungai Bahar Kabupaten Muaro Jambi

Sedangkan untuk menghitung total pengeluaran (TC) usahatani kelapa sawitPasca Umur Produktif digunakan rumus (Soekartawi, 2002) yaitu,

\section{$\mathbf{T C}=\mathbf{T F C}+\mathbf{T V C}$}

Dimana :

$\mathrm{TC}=$ Biaya Produksi Total $(\mathrm{Rp} / \mathrm{Ha} /$ Bulan $)$

$\mathrm{TFC}=$ Biaya Tetap $(\mathrm{Rp} / \mathrm{Ha} / \mathrm{Bulan})$

$\mathrm{TVC}=$ Biaya Variabel $(\mathrm{Rp} / \mathrm{Ha} /$ Bulan $)$

Dalam penelitian ini untuk menentukan biaya penyusutan maka digunakan rumusberikut (Syafri, 2002)

$D=\frac{c-s}{n}$

Dimana :

$\mathrm{D}=$ Biaya Penyusutan Alat (Rp/Ha/Bulan)

$\mathrm{C}=$ Nilai Awal Alat $(\mathrm{Rp})$

$\mathrm{S}=$ Nilai Akhir Alat $(\mathrm{Rp})$

$\mathrm{N}=$ Umur Ekonomis (Bulan)

\section{Identitas Petani Sampel}

\section{HASIL PENELITIAN}

Identitas petani sampel adalah ciri-ciri yang dimiliki oleh petani dalam hubungannya dengan usaha sebagai petani nanas yang terdiri dari: (1) umur petani (2) pengalaman berusahatani (3) tingkat pendidikan (4) jumlah tanggungan keluarga, (5) luas lahan.

Dari hasil penelitian, diketahui bahwa umur petani terendah adalah 38 tahun dan tertinggi 62 tahun, dengan rata-rata umur petani sampel adalah 50,07 tahun. Hal ini menunjukkan bahwa umur petani sampel di daerah penelitian masih tergolong produktif. Untuk lebih jelasnya dapat dilihat pada Tabel 1.

Tabel 1. Distribusi Frekuensi dan Persentase Petani Berdasarkan Umur diDesa Bukit Makmur Tahun 2020

\begin{tabular}{cccc}
\hline No. & Kelompok Umur (Tahun) & Frekuensi (Orang) & Persentase (\%) \\
\hline 1 & $38-42$ & 4 & 9,76 \\
2 & $43-47$ & 8 & 19,52 \\
3 & $48-52$ & 15 & 36,58 \\
4 & $53-57$ & 12 & 29,26 \\
5 & $58-62$ & 2 & 4,88 \\
6 & $63-67$ & 0 & 0 \\
\hline \multicolumn{7}{c}{} & Jumlah & $\mathbf{4 1}$ & $\mathbf{1 0 0}$ \\
\hline
\end{tabular}

Sumber: Hasil Olahan Data Primer 2020

Tabel 1 menunjukkan bahwa jumlah petani sampel yang memiliki persentase tertinggi berada pada umur 48 - 52 tahun yaitu 15 orang atau sebesar 36,58\%. Sedangkan jumlah petani sampel dengan persentase terendah berada pada umur $58-62$ tahun yaitu 2 orang atau sebesar $4,88 \%$. Hal ini menunjukkan bahwa umur petani sampel di daerah penelitian masih tergolong produktif. Umur merupakan salah satu faktor dari seseorang yang mempengaruhi aktifitas biologis dan aspek psikologis. Selain itu, umur juga dapat mempengaruhi fisik dan cara berpikir petani. Tingkat usia seorang petani sangat menentukan produktivitas kerja dalam mengelola usahataninya. Semakin petani berumur, maka kemampuannya dalam bekerja akan cenderung menurun. Pernyataan ini sesuai dengan pendapat Hernanto (1998), bahwa pada umumnya petani yang lebih muda dan sehat mempunyai kemampuan fisik lebih cepat menerima hal-hal baru yang dianjurkan, hal ini disebabkanpetani muda lebih berani mengambil resiko.

Usia produktif adalah mereka yang bekerja pada usia 15 - 50 tahun, dimana pada usia tersebut seseorang masih memiliki kemampuan fisik yang baik untuk mengelola usahanya. Menurut Hernanto (1998), usia produktif adalah mereka yang bekerja pada usia 15 - 50 tahun, dimana pada usia tersebut seseorang masih memiliki kemampuan fisik yang baik untuk mengelola usahanya. Dengan kondisi petani yang rata-rata berumur produktif diharapkan mampu mengelola usahataninya secara maksimal guna meningkatkan produksi sehingga petani dapat memperoleh pendapatan yang lebih tinggidan dapat digunakan untuk memenuhi kelangsungan hidup rumah tangganya yang berdampak terhadap kesejahteraan petani di daerah penelitian.

Pengalaman berusahatani berperan dalam pembentukan sikap dan pola pikir petani serta keterampilan petani dalam berusahatani. Dalam penelitian ini pengalaman petani sampel adalah pengalaman petani dalam 
Nida Kemala, Wiwin Alawiyah dan Prasetyo Yuanwiarno. Pendapatan Usahatani Kelapa Sawit Pasca Umur Produktif di Desa Bukit Makmur Kecamatan Sungai Bahar Kabupaten Muaro Jambi

berusahatani kelapa sawit dalam jumlah tahunan. Pengalaman berusahatani kelapa sawit di Desa Bukit Makmur berkisar antara 10 - 32 tahun, dengan rata-rata pengalaman bertani petani sampel di daerah penelitian adalah 22,10 tahun. Untuk lebih jelasnya distribusi pengalaman berusahatani petani sampel dapat dilihat pada Tabel 2.

Tabel 2. Distribusi Petani Sampel Berdasarkan Pengalaman Berusahatanidi Desa Bukit Makmur Tahun 2020

\begin{tabular}{cccc}
\hline No. & Pengalaman Berusahatani(Tahun) & Frekuensi(Orang) & Persentase(\%) \\
\hline 1 & $10-13$ & 4 & 9,76 \\
2 & $14-17$ & 1 & 2,44 \\
3 & $18-21$ & 12 & 29,26 \\
4 & $22-25$ & 14 & 34,15 \\
5 & $26-29$ & 8 & 19,51 \\
6 & $30-33$ & 2 & 4,88 \\
\hline & Jumlah & $\mathbf{4 1}$ & $\mathbf{1 0 0}$ \\
\hline
\end{tabular}

Sumber: Hasil Olahan Data Primer 2020

Tabel 2 menunjukkan bahwa persentase tertinggi pengalaman berusahatani petani sampel berada diantara $22-25$ tahun yaitu 14 orang atau sebesar $34,15 \%$. Sedangkan persentase terendah pengalaman berusahatani berada pada tingkat $14-17$ tahun yaitu sebanyak 1 orang atau sebesar $2,44 \%$.

Pengalaman berusahatani menunjukkan bahwa petani sampel di daerah penelitian sudah memiliki pengalaman yang cukup lama dalam berusahatani kelapa sawit. Sejalan dengan pendapat Soeharjo dan Patong (1977) semakin lama seseorang mengelola usahatani maka kapasitas pengelolaan usahataninya akan semakin matang. Dari pendapat diatas jika dihubungkan dengan hasil penelitian, maka sudah semestinya petani sampel mempunyai kemampuan yang lebih baik dalam mengelola usahatani kelapa sawit yang dimilikinya sehingga dapat meningkatkan kualitas dan produktifitas usaha tani kelapa sawit.

Tingkat pendidikan petani akan mempengaruhi intelektualitas dan kesediaan mencoba hal baru (inovasi), karena pendidikan itu sendiri bertujuan untuk merubah tingkah laku dan pola pikir petani. Tingkat pendidikan dalam penelitian ini juga berpengaruh terhadap kemampuan petani dalam pembentukan modal yang digunakan untuk biaya peremajaan kebun kelapa sawit. Pendidikan petani sampel diukur berdasarkan tingkat pendidikan formal yang pernah dilaluinya. Adapun keadaan penyebaran petani sampel didaerah penelitian berdasarkan tingkat pendidikan formalnyadapat dilihat pada Tabel 3 .

Tabel 3. Distribusi Petani Sampel Berdasarkan Tingkat Pendidikan Formaldi Desa Bukit Makmur Tahun 2020

\begin{tabular}{cccc}
\hline No & Pendidikan Formal & Frekuensi (Orang) & Persentase (\%) \\
\hline 1 & SD & 22 & 53,66 \\
2 & SMP & 11 & 26,83 \\
3 & SMA & 7 & 17,07 \\
4 & S-1 & 1 & 2,44 \\
\hline & Jumlah & $\mathbf{4 1}$ & $\mathbf{1 0 0}$ \\
\hline
\end{tabular}

Sumber: Hasil Olahan Data Primer 2020

Pendidikan SD Sederajat adalah petani yang paling banyak yaitu 22 Orang atau sebesar 53,66\%. Sedangkan pendidikan tertinggi yaitu S-1 hanya dimiliki oleh satu orang petani sampel atau sebesar $2,44 \%$. Menurut Soeharjo dan Patong (1977) yang menyatakan bahwa semakin tinggi tingkat pendidikan seseorang maka semakin efisien cara bekerja yang akan dilakukan dalam mempengaruhi cara berfikir untuk mengambil keputusan dan memilih alternatif yang terbaik dalam usahatani yang dilakukan, begitu juga sebaliknya.

Jumlah tanggungan keluarga yang dimaksud dalam penelitian ini adalahbanyaknya jumlah jiwa yang ditanggung dalam rumah tangga petani sampel. Jumlah tanggungan keluarga akan mempengaruhi tingkat produktivitas kerja dikaitkan dengan jumlah penggunaan (sumbangan) tenaga kerja dalam keluarga terhadap kegiatan produksi usahatani. Semakin banyak jumlah tanggungan keluarga maka semakin banyakpula tenaga kerja dalam keluarga yang dapat digunakan dalam kegiatan produksi usahatani sehingga dapat mengurangi biaya yang harus dikeluarkan untuk tenaga kerja luar keluarga.

Jumlah tanggungan keluarga akan berhubungan dengan pola konsumsi rumah tangga. Semakin banyak jumlah tanggungan keluarga semakin banyak kebutuhan konsumsi yang harus dipenuhi oleh rumah tangga dan sebaliknya semakin sedikit jumlah tanggungan keluarga semakin sedikit kebutuhan yang harus ditanggung oleh rumah tangga. Keadaan penyebaran petani sampel di daerah penelitian berdasarkan jumlah tanggungan keluarga dapat dilihat pada Tabel 4. 
Nida Kemala, Wiwin Alawiyah dan Prasetyo Yuanwiarno. Pendapatan Usahatani Kelapa Sawit Pasca Umur Produktif di Desa Bukit Makmur Kecamatan Sungai Bahar Kabupaten Muaro Jambi

Tabel 4. Distribusi Petani Sampel Berdasarkan Jumlah TanggunganKeluarga di Desa Bukit Makmur Tahun 2020

\begin{tabular}{cccc}
\hline No. & $\begin{array}{c}\text { Jumlah Tanggungan } \\
\text { Keluarga (Orang) }\end{array}$ & $\begin{array}{c}\text { Frekuensi } \\
\text { (Orang) }\end{array}$ & $\begin{array}{c}\text { Persentase } \\
(\boldsymbol{\%})\end{array}$ \\
\hline 1 & 2 & 13 & 31,70 \\
2 & 3 & 17 & 41,46 \\
3 & 4 & 10 & 24,40 \\
4 & 5 & 1 & 2,44 \\
5 & 6 & 0 & 0 \\
6 & 7 & 0 & 0 \\
\hline
\end{tabular}

Sumber: Hasil Olahan Data Primer 2020

Tabel 4 menunjukkan bahwa persentase tertinggi jumlah tanggungan keluarga petani sampel adalah 3 orang yaitu sebesar 17 orang atau $41,46 \%$. Sedangkan persentaseterendah pada jumlah tanggungan keluarga adalah 5 orang yaitu sebesar 1 orang atau 2,44\%. Dengan rata-rata jumlah tanggungan keluarga sebanyak 3 orang.

Jumlah tanggungan keluarga petani sampel di daerah penelitian berhubungan dengan kemampuan petani dalam memenuhi kebutuhan konsumsi rumah tangganya yang berpengaruh terhadap pelaksanakan peremajaan kebun kelapa sawit. Sebagai kepala keluarga, harus bertanggung jawab terhadap kesejahteraan dan pemenuhan hidupseluruh tanggungan keluarga.

Jumlah tangungan keluarga merupakan modal tenaga kerja dalam keluarga. Hal ini sesuai dengan pendapat Hernanto (1998) yang menyatakan bahwa jumlah anggota keluarga sangat berpengaruh dalam pengelolaan suatu kegiatan ekonomi, khususnya terhadap kegiatan ekonomi pada usahatani.

Lahan merupakan faktor produksi yang utama dalam berusahatani. Menurut Suratiyah, K (2015) semakin luas lahan yang diusahakan maka semakin tinggi produksi dan pendapatan per satuan luasnya. Dengan lahan yang luas maka petani dapat menghasilkan produksi yang tinggi apabila usahatani tersebut dikelola dengan baik, begitu juga sebaliknya petani yang mempunyai lahan sempit akan berproduksi sedikit ditambah lagi jika tidak dikelola dengan baik. Luas lahan yang dimaksud dalam penelitian adalah luas lahan usahatani kelapa sawit yang diusahakan oleh petani sampel.Berikut distribusi luas lahan usahatani kelapa sawit di daerah penelitian.

Tabel 5. Distribusi Petani Sampel Berdasarkan Luas Lahan di Desa BukitMakmur Tahun 2020

\begin{tabular}{cccc}
\hline No. & Luas Lahan(Ha) & Frekuensi(Orang) & Persentase(\%) \\
\hline 1 & $2,00-3,09$ & 18 & 43,90 \\
2 & $3,10-4,19$ & 18 & 43,90 \\
3 & $4,20-5,29$ & 3 & 7,32 \\
4 & $5,30-6,39$ & 1 & 2,44 \\
5 & $6,40-7,49$ & 0 & 0 \\
6 & $7,50-8,59$ & 1 & 2,44 \\
\hline & Jumlah & $\mathbf{4 1}$ & $\mathbf{1 0 0}$
\end{tabular}

Sumber: Hasil Olahan Data Primer 2020

Tabel 5 menunjukkan bahwa luas lahan kelapa sawit yang diusahakan petani cukup bervariasi. Luas lahan petani terkecil yaitu $2 \mathrm{Ha}$, sedangkan luas lahan terbesar petani adalah $8 \mathrm{Ha}$. Persentase tertinggi luas lahan yang dimiliki oleh petani adalah 2,00-3,09 Ha dan 3,10-4,19 Ha sebanyak 18 orang atau 43,90\%. Sedangkan persentase luas lahan terendah yaitu 5,30 - 6,39 Ha dan 7,50-8,59 Ha sebanyak 1 orang dengan persentase 2,44\%. Rata - rata luas lahan kelapa sawit yang dimiliki petani adalah 3,54 Ha. Tinggi rendahnya luas lahan yang dimiliki petani tentunya akan berpengaruh terhadap produksi yang dihasilkan dan berpengaruh terhadap pendapatan yang diterima oleh petani. Luas lahan yang tinggi juga akan berpengaruh terhadap luas lahan yang dapat diremajakan oleh petani sampel.

\section{Gambaran Kegiatan Usahatani Kelapa Sawit Di Desa Bukit Makmur}

Kelapa sawit merupakan tanaman yang sudah diusahakan sejak lama oleh warga Desa Bukit Makmur Kecamatan Sungai Bahar Kabupaten Muaro Jambi. Usahatani kelapa sawit merupakan program dari pemerintah bagi masyarakat dari jawa yang mau mengikuti program transmigrasi. Bibit dan lahan yang dimiliki petani adalah lahan yangdiberikan oleh pemerintah secara gratis dan lahan tersebut dijadikan sumber penghasilantetap dan penghasilan tambahan bagi warga Desa Bukit Makmur. Rata - rata luas lahan yang dimiliki petani di Desa Bukit 
Nida Kemala, Wiwin Alawiyah dan Prasetyo Yuanwiarno. Pendapatan Usahatani Kelapa Sawit Pasca Umur Produktif di Desa Bukit Makmur Kecamatan Sungai Bahar Kabupaten Muaro Jambi

Makmur adalah 3,54 Ha dengan status milik pribadi. Mayoritas tanaman kelapa sawit sudah berumur tua dengan rata - rata umur tanaman 28,85 tahun.

Menurut Mangoensoekarjo (2007), pupuk sangat menentukan keberhasilan budidaya tanaman kelapa sawit dalam rangka mencapai tingkat produksi yang ekonomis. Kemampuan tanah untuk menyediakan unsur hara secara cukup dan terus- menerus sangat terbatas dan semakin lama kebutuhan unsur hara menjadi berkurang. Oleh karna itu dilakukan pemupukan yang bertujuan untuk meningkatkan kesuburan tanah sehingga kebutuhan unsur hara tanaman tercukupi dan produksi tanaman akan meningkat serta daya tahan tanaman terhadap serangan hama dan penyakit. Pupuk yang digunakan petani yaitu Urea, NPK, dan KCL dengan rotasi $2 x$ setahun. Pupuk Urea di aplikasikan dengan dosis rata - rata 619 Kg/rotasi, Pupuk NPK 144 Kg/ Rotasi dan Pupuk KCL 52 Kg/Rotasi. Pemupukan berfungsi untuk memenuhi unsur hara yang diperlukan tanaman agar dapat tumbuh dan berproduksi secara optimal.

Dalam pemupukan sudah mengikuti aspek pemupukan 4T, Yaitu Tepat jenis, dosis, waktu dan metode. Dosis pupuk ditentukan berdasarkan umur tanaman, hasil analisa daun, jenis tanah, produksi tanaman, hasil percobaan dan kondisi visual tanaman.

Pemupukan dilakukan dengan 2 cara, yaitu sistem tebar dan sistem benam (Pocket). Pemupukan dengan sistem tebar dilakukan dengan menaburkan pupuk di piringan tanaman tepatnya dibawah ujung pelepah daun kelapa sawit. Pada sistempocket, pupuk diberikan dengan cara membuat 4-6 lubang pada sekeliling pokok kelapa sawit dan berada diujung pelepah daun kelapa sawit. Hal ini dilakukan karna dibawah ujung pelepah daun kelapa sawit banyak terdapat akar muda yang aktif sehingga unsur hara pupuk dapat diserap secara optimal oleh tanaman. Sistem pocket disarankan pada areal rendahan, areal berbukit ataupun pada tanah pasiran yang mudah tercuci/tererosi. Pada tapak kuda, $75 \%$ pupuk diberikan pada areal dekat tebing dengan tujuan untuk mengurangi pencucian, pupuk ini sebaiknya diaplikasikan dengan sistem pocket.

Petani di Desa Bukit Makmur sudah mengurangi penggunaan pupuk dikarenakan tanaman yang sudah berumur tua tidak dapat menyerap unsur hara secara optimal sehingga tidak dapat meningkatkan produksi dan hanya menambah biaya bagi petani. Dengan mengurangi biaya pemupukan maka petani mengurangi biaya produksi sehingga pendapatan akan bertambah.

Pengendalian gulma bertujuan agar tidak ada persaingan unsur hara antara tanaman utama dengan tanaman yang ada disekitarnya. Pengendalian gulma dilakukan dengan cara menyemprot gawangan dan jalan panen sehingga saran produksi panen dapat berjalan dengan baik. Pengendalian gulma menggunakan pestisida dengan merk dagang round-up, gramoxone dan starlon. Round - up memiliki bahan aktif Glifosat yang berfungsi untuk membunuh gulma lunak seperti ilalang. Gramoxone berfungsi untuk mengendalikan gulma daun lebar seperti anakan sawit, paku pakuan. Sedangkanstarlon digunakan untuk mengendalikan gulma berkayu seperti tumbuhan senduduk, putri malu, dan lain - lain.

Pengolahan dan perawatan usahatani kelapa sawit di Desa Bukit Makmur dilakukan secara manual, alat yang digunakan antara lain seperti cangkul, parang, dan tangki semprot. Pemanenan kelapa sawit menggunakan alat seperti egrek, parang, lori dan tojok.

Panen adalah kegiatan pemotongan tandan buah yang matang dari pohon hingga pengangkutan ke pabrik pengolahan kelapa sawit. Panen merupakan kegiatan penting pada tanaman menghasilkan dan menjadi sumber pemasukan uang bagi perusahaan. Keberhasilan panen dan produksi tergantung pada kegiatan budidaya serta ketersediaan sarana untuk transportasi, pengolahan, organisasi, tenaga kerja, faktor penunjang lainnya. Peralatan panen dengan kualitas yang baik sangat menentukan kualitas dan kuantitas panen. Peralatan panen yang digunakan dalam pemanenan antara lain :

1. Egrek

Egrek merupakan peralatan panen yang digunakan untuk memanen TBS pada tanaman yang tinggi (> 8 tahun). Egrek berbentuk seperti sabit yang disambung menggunakan galah atau gagang alumunium. Dalam gagang alumunium terdapat tiga buah galah dengan panjang masing - masing enam meter dan panjangnya dapat disesuaikan.

2. Parang

Parang merupakan alat panen yang digunakan untuk memotong tangkai tandan TBS yang masih panjang dan digunakan sebagai alat untuk memotong pelepah menjadi tiga bagian sebelum disusun di gawangan mati.

3. Tojok/Tombak

Tojok terbuat dari besi yang ujungnya runcing dan tajam. Pada bagian pegangan tangan atau bagian atas tojok disambung besi kecil sehingga berbentuk seperti huruf " $T$ ". Tojok digunakan untuk mengangkat buah dari dalam kebun ke dalam Lori/gerobak dan untuk menyusun tandan buah segar (TBS) di dalam Truk.

4. Lori/Gerobak

Lori/gerobak digunakan untuk mengangkut tandan buah segar (TBS) yang telah dipanen dari dalam kebun 
menuju ke tempat pengumpulan hasil (TPH).

Tenaga kerja dalam usahatani kelapa sawit ada yang berasal dari dalam keluarga dan ada yang berasal dari luar keluarga. Jumlah tenaga kerja yang digunakan dalam suatu kegiatan usahatani sangat berpengaruh terhadap pendapatan usahatani tersebut. Apabila lebih banyak tenaga kerja yang digunakan dari luar keluarga maka akan memperbesar biaya produksi yang harus dikeluarkan petani.

Semua pekerjaan dalam pengelolaan dan perawatan dan pemanenan sebagian besar dikerjakan sendiri oleh petani di Desa Bukit Makmur, hanya beberapa pekerjaan saja yang menggunakan tenaga kerja dari luar keluarga. Hal ini dilakukan oleh para petani untuk menekan biaya produksi sehingga pendapatan mereka bisa bertambah.

Pemasaran hasil produksi usahatani kelapa sawit di Desa Bukit Makmur dilakukan langsung oleh petani ke Koperasi dan Toke (Pengepul). Harga beli buah yang ditawarkan ke petani yaitu Rp.1500 - Rp.1.600/Kg. Pembayaran dilakukan langsung oleh Toke (Pengumpul) setelah semua hasil produksinya ditimbang, sedangkan jika menjual ke Koperasi maka pembayaran dilakukan Keesokan harinya setelah hasil produksi ditimbang.

\section{Pendapatan Usahatani Kelapa Sawit Biaya Produksi}

Biaya produksi adalah semua biaya yang dikeluarkan selama proses produksi. Hernanto (1998) mengatakan bahwa korbanan yang dicurahkan dalam proses produksi ini yang semula fisik, kemudian diberi nilai rupiah dan itulah yang kemudian diberi istilah biaya. Dalam usahatani kelapa sawit biaya produksi meliputi biaya tetap dan biaya tidak tetap. Biaya produksi merupakan cerminan dari produksi, bila produksi merujuk kepadajumlah input yang dipakai dan jumlah output yang dihasilkan, biaya produksi merujuk kepada biaya peroleh input tersebut (nilai uangnya). Menurut Soekartawi (2002), bahwabiaya memiliki peranan yang sangat penting dalam pengambilan keputusan usahataninya. Besarnya biaya yang dikeluarkan untuk memproduksi sesuatu ditentukan oleh besarnya harga pokok dari produk yang dihasilkan.

Menurut Nicholson (2002), Biaya secara garis besarnya terdiri dari dua, yaitu biaya tetap dan biaya variabel. Biaya dilihat dari segiwaktu terbagi menjadi dua, yaitu biaya jangka pendek dan biaya jangka panjang. Jangka pendek merupakan periode waktu dimana sebuah perusahan harus mempertimbangkan beberapa inputnya secara absolut bersifat tetap dalam membuat keputusannya. Jangka panjang merupakan periode waktu dimana sebuah perusahan mempertimbangkan seluruh inputnya bersifat variabel dalam membuat keputusannya.

Menurut Antoni (1995), biaya-biaya yang dikeluarkan dalam memproduksi kelapasawit mencakup :

1. Biaya investasi awal seperti: pembukaan lahan, biaya bibit, serta biaya pemeliharaan sebelum tanaman menghasilkan

2. Biaya pemeliharaan tanaman, seperti: pemberantasan gulma, pemupukan, pemberantasan hama dan penyakit, tunas pokok (pruning), konsolidasi, pemeliharaan terasan dan tapak kuda, pemeliharaan prasarana.

3. Biaya panen atau biaya yang dikeluarkan untuk melancarkan segala aktivitas untuk mengeluarkan produksi (TBS) atau hasil panen dari lapangan (areal) ke agen pengepul atau kepabrik seperti biaya tenaga kerja panen, biaya pengadaan alat kerja dan biaya angkutan.

Biaya tetap adalah biaya yang tidak habis dipakai dalam satu kali proses produksi,yang dihitung berdasarkan nilai penyusutan. Biaya tetap terdiri dari biaya cangkul, egrek, parang, tangki semprot, tojok/tombak dan lori/gerobak.

Sedangkan biaya tidak tetap adalah biaya yang habis dalam satu kali proses produksi. Biaya tidak tetap terdiri dari pembelian pupuk, biaya pembelian obat - obatan,dan biaya tenaga kerja. Berikut adalah biaya biaya yang dikeluarkan petani dalam usahatani kelapa sawit di daerah penelitian. 
Nida Kemala, Wiwin Alawiyah dan Prasetyo Yuanwiarno. Pendapatan Usahatani Kelapa Sawit Pasca Umur Produktif di Desa Bukit Makmur Kecamatan Sungai Bahar Kabupaten Muaro Jambi

Tabel 6. Rincian Biaya Produksi Usahatani Kelapa Sawit di Desa Bukit MakmurTahun 2020

\begin{tabular}{|c|c|c|c|}
\hline No. & Komponen Biaya & $\begin{array}{c}\text { Jumlah } \\
\text { (Rp/Ha/Bulan) }\end{array}$ & Persentase (\%) \\
\hline \multirow[t]{7}{*}{1.} & Biaya Tetap & 21.630 & $4,10 \%$ \\
\hline & 1. Cangkul & 1.493 & 0,29 \\
\hline & 2. Egrek & 5.935 & 1,13 \\
\hline & 3. Parang & 2.222 & 0,42 \\
\hline & 4. Tangki Semprot & 4.513 & 0,85 \\
\hline & 5. Tojok/Tombak & 1.336 & 0,25 \\
\hline & 6. Lori/Gerobak & 6.130 & 1,16 \\
\hline \multirow[t]{5}{*}{2.} & Biaya Tidak Tetap & 507.202 & $95,90 \%$ \\
\hline & 1. Pupuk & 142.506 & 26,95 \\
\hline & 2. Obat - obatan & 155.026 & 29,31 \\
\hline & 3. Tenaga Kerja & 209.670 & 39,64 \\
\hline & Jumlah Total Biaya & 528.832 & $100 \%$ \\
\hline
\end{tabular}

Sumber : Data Primer yang diolah Tahun 2020

Dapat dilihat biaya terbesar yang dikeluarkan petani adalah biaya tidak tetap yaitu sebesar 95,90\% dari total semua biaya produksi usahatani kelapa sawit. Biaya tidak tetap terdiri dari biaya pupuk, biaya obat - obatan dan biaya tenaga kerja dengan total biaya sebesar Rp. 507.202/ha/bulan. Sedangkan biaya tetap berjumlah Rp.21.630/ha/bulan dengan persentase 4,10 \% dari total biaya produksi usahatani kelapasawit. Biaya tetap berasal dari biaya penyusutan alat seperti cangkul, egrek, parang, tangki semprot, tojok/tombak dan lori/gerobak.

\section{Penerimaan Usahatani Kelapa Sawit}

Penerimaan usahatani yang dimaksud dalam penelitian adalah total penerimaan yang berasal dari usahatani kelapa sawit yang belum diremajakan. Penerimaan usahatani dihitung dalam kurun waktu satu tahun. Menurut Suratiyah, K (2015), penerimaan usahatani adalah pendapatan yang diperoleh dari usahatani selama satu periode diperhitungkan dari hasil penjualan atau penaksiran kembali. Jumlah penerimaan yang diterima petani dalam penelitian ini dapat ditentukan dengan mengalikan jumlah produksi TBS perbulan dengan harga TBS per bulan.

Hasil penerimaan usahatani kelapa sawit di Desa Bukit Makmur per hektar per bulan berkisar Rp.1.015.800 - Rp.2.686.400 dengan rata-rata penerimaan usahatani kelapa sawit sebesar Rp.1.311.417/Ha/Bulan. Bentuk penerimaan tunai dapat menggambarkan tingkat kemajuan ekonomi usahatani dalam spesialisasi dan pembagian kerja. Besarnya pendapatan tunai atau besarnya proporsi penerimaan tunai dari total penerimaan dapat digunakan untuk perbandingan keberhasilan petani satu terhadap yang lain. Dengan demikian jika kita mencoba menerapkan perbandingan tersebut menjadi invailid dan tidak sepenuhnya benar, dalam masyarakat yang demikian penerimaan tunai hanya merupakan sebagian kecil saja, sedangkan yang terbesar berupa penerimaan dalam bentuk natura yang dikonsumsi keluarga (Dalas, 2004).

\section{Pendapatan Usahatani Kelapa Sawit}

Pendapatan usahatani kelapa sawit adalah besarnya pendapatan dari usahatani kelapa sawit yang dimiliki dan dikelola oleh petani secara mandiri. Pendapatan diartikansebagai selisih antara besarnya penerimaan dan biaya yang dikeluarkan. Selain itu pendapatan dapat digambarkan sebagai balas jasa dan kerja sama faktor-faktor produksi yang disediakan oleh petani sebagai pengelola, pekerja dan sebagai pemilik modal. Dalam meningkatkan pendapatan, maka petani harus meningkatkan hasil produksi serta menekan biaya produksi agar memperoleh peningkatan pendapatan dengan maksimal.

Dalam rumah tangga, pendapatan merupakan alat untuk memenuhi kebutuhan konsumsi keluarga. Dengan adanya pendapatan, maka rumah tangga akan dapat memenuhi kebutuhannya sesuai dengan pendapatan yang diperolehnya. Untuk lebih jelasnya dapat dilihat pada Tabel 7.

Tabel 7. Rata - rata Pendapatan Usahatani Kelapa Sawit Di Desa Bukit MakmurTahun 2020

\begin{tabular}{ccc}
\hline Uraian & Satuan & Jumlah \\
\hline Jumlah Produksi & $\mathrm{Kg} / \mathrm{Ha} / \mathrm{Bulan}$ & 2.908 \\
Harga Produk & $\mathrm{Rp} / \mathrm{Kg}$ & 1.534 \\
Penerimaan & $\mathrm{Rp} / \mathrm{Ha} / \mathrm{Bulan}$ & 1.311 .417 \\
Biaya Produksi & $\mathrm{Rp} / \mathrm{Ha} / \mathrm{Bulan}$ & 528.832 \\
Pendapatan & $\mathrm{Rp} / \mathrm{Ha} / \mathrm{Bulan}$ & 782.585 \\
\hline
\end{tabular}

Sumber : Data Primer yang diolah Tahun 2020 
Hasil penelitian terhadap pendapatan usahatani kelapa sawit di Desa Bukit Makmur dengan total pendapatan per hektar per bulan berkisar Rp 300.913-2.189.206 dengan rata-rata pendapatan petani sebesar Rp.782.585/Ha/Bulan. Keberhasilan kegiatan usahatani apabila situasi pendapatan dapat menghasilkan cukup pendapatan untuk membayar semua biaya produksi, dan cukup untuk membayar bunga modal yang ditanam. Petani sebagai pelaksana mengharapkan produksi yang lebih besar agar memperoleh pendapatan yang besar pula. Untukitu, petani menggunakan tenaga, modal dan sarana produksinya sebagai umpan untuk mendapatkan produksi yang diharapkan. Ada kalanya produksi yang diperoleh justru lebih kecil dan sebaliknya (Suratiyah, 2011).

Pendapatan yang diterima seorang petani dalam satu tahun akan berbeda dengan pendapatan yang diterima petani lainnya. Bahkan seorang petani yang mengusahakan luas lahan yang sama akan menerima pendapatan yang berbeda juga dari tahun ketahun, hal ini disebabkan perbedaan penggunaan faktor produksi yang digunakan akan mempengaruhi produksi yang dihasilkan sehingga berdampak terhadap pendapatan.

Adanya perbedaan pendapatan yang diperoleh petani sampel dipengaruhi oleh jumlah produksi yang diperoleh, luas lahan yang dimiliki petani serta penggunaan faktor produksi lainnya.

Besarnya pendapatan usahatani dapat menjadi tolak ukur keberhasilan petani dalam mengelola usahataninya. Pendapatan usahatani dipengaruhi oleh hasil produksi dan biaya produksi dari usahatani tersebut. Peningkatan pendapatan akan diperoleh apabila investasi yang dilakukan petani menguntungkan, sehingga petani dapat memberi keputusan apakah investasi yang dilakukan petani akan berlanjut atau tidak. Tanpa keuntungan yang layak petani akan menentukan pilihan usahatani lain atau petani berganti komoditas lain yang lebih menguntungkan sehingga dapat meningkatkan keuntungan dan taraf hidup petani.

Analisis pendapatan digunakan untuk mengukur keberhasilan dari usahatani yang dilakukan dan dapat menggambarkan keadaan kegiatan usahatani sehingga dapat menyusun rencana dan tindakan didalam suatu kegiatan usahatani.

Berdasarkan wawancara yang dilakukan oleh peneliti petani masih mengusahakan tanaman pasca umur produktif dikarenakan biaya peremajaan sangatlah tinggi, adapun bantuan pemerintah berupa subsidi dan harga bibit yang murah tidak membuat petani seutuhnya langsung meremajakan semua tanaman kelapa sawitnya, mereka meremajakan tanaman yang memang sama sekali tidak menghasilkan buah lagi, jika masih berbuah $2-3 \operatorname{tandan}$ buah segar mereka masih tetap menunggu dari hasiltersebut, namun penghasilan yang mereka dapat dari tanaman hasil pasca umur produktif tidaklah begitu memuaskan bagi petani, mereka juga memanfaatkan sisa sisa tanah yang kosong di sekitar pinggiran tanaman kelapa sawit berupaya sayur-sayuran yang dapat dipanen $1-2$ minggu untuk memenuhi kebutuhan hidupnya, karena harus menunggu tanaman yang diremajakan/Pohon Baru selama $2-3$ Tahun setelah masa peremajaan.

Upah Minimum Provinsi Jambi (UMP) ditetapkan sesuai dengan Keputusan Gubernur Jambi No.220/KEP.GUB/DISNAKERTRANS-3.3/2019 Tahun 2019 yaituSebesar Rp. 2.630.162, Jika dibandingkan dengan Upah Minimum Provinsi, pendapatan petani masih jauh untuk memenuhi standar upah yang ditetapkan oleh pemerintah.

\section{KESIMPULAN}

1. Rata-rata luas lahan yang dimiliki petani adalah $3,54 \mathrm{Ha}$ dengan status milik pribadi dan mayoritas tanaman kelapa sawit sudah berumur tua rata - rata 28,85 tahun.Pengendalian gulma dilakukan dengan cara menyemprotkan racun/pestisida. Pupuk yang digunakan petani adalah pupuk urea,NPK, dan KCL dengan rotasi 2x setahun.

2. Rata - rata produksi hasil usahatani kelapa sawit adalah $2.908 \mathrm{~kg} / \mathrm{Ha} / \mathrm{bulan}$. Penerimaan berkisar antara Rp.1.015.800-2.686.400/Ha/Bulan dengan rata-rata penerimaan sebesar Rp. 1.311.417/Ha/Bulan dengan biaya Produksi sebesar Rp. 528.832 /Ha/Bulan. Sedangkan total pendapatan berkisar antara Rp 300.9132.189.206/Ha/Bulan dengan rata-rata pendapatan petani sebesar Rp. 782.585/Ha/Bulan.

\section{DAFTAR PUSTAKA}

Adiwilaga, A. 1992. Ilmu Usaha Tani. Cetakan ke-III. Alumni. Bandung

Agustin, S. 2019. Analisis Pendapatan Usahatani Kelapa Sawit di Desa Tebo Jaya Kecamatan Limbur Lubuk Mengkuang Kabupaten Bungo. Skripsi Fakultas Pertanian Universita Batanghari. Jambi

Antoni, R. 1995. Pengendalian Gulma, Pemupukan, Pengelolaan Tajuk danManajemen Pemungutan Hasil Kelapa Sawit (Elais guinesis) diKayangan Estate, PT.Salim Indoplantation. Riau. Laporan KeterampilanPropesi Jurusan Budidaya Pertanian. Fakultas Pertanian Bogor.

Dinas Perkebunan Provinsi Jambi. 2017. LaporanTahunan Disbun Provinsi Jambi, Jambi.

Fauzi, Y, Y. Erma. Widyastuti, I. Satyawibawa dan R. Hartono. 2005. Kelapa Sawit.

Penebar Swadaya. Jakarta. 
Nida Kemala, Wiwin Alawiyah dan Prasetyo Yuanwiarno. Pendapatan Usahatani Kelapa Sawit Pasca Umur Produktif di Desa Bukit Makmur Kecamatan Sungai Bahar Kabupaten Muaro Jambi

Ginting, Eko. N, Sutarta E. S, Rahutomo S, Santoso H, Susanto A. 2008. Peremajaan Tanaman Kelapa Sawit Sistem Underplanting. Medan, Pusat Penelitian Kelapa Sawit.

Hasibuan, B. E. 2011. Ilmu Tanah. Universitas Sumatera Utara. Medan.Hernanto F. 1989. Ilmu Usahatani. Penebar Swadaya. Jakarta.

Hermansyah. (2011). penelitian Analisa Pendapatan Usahatani Kelapa sawit Pasca Umur Ekonomis ( 27 Tahun ) pada Perkebunan Sawit Inti Rakyat di KecamatanLuhak Nan Duo Kabupaten Pasaman Barat (Studi Kasus: KPS Sejahtera Pir-Bun Ophir). Uviversitas Padang. Padang

Husein, Umar. 2011. Metode Penelitian untuk Skripsi dan Tesis Bisnis. Raja Grafindo Persada. Jakarta.

Junaidi. 2016 Analisis Pendapatan Usaha Tani Kelapa Sawit Di Desa Panton Pange Kecamatan Tripa Makmur Kabupaten Nagan Raya Fakultas Pertanian Universitas Teuku Umar Meulaboh, Aceh Barat.

Mangoensoekarjo, S. dan H. Samangun, 2008. Manajemen Agribisnis Kelapa Sawit. UGM-Press . Yogyakarta

Mubyarto et al. 2004. Tanah dan Tenaga Kerja Perkebunan Kajian Sosial Ekonomi. Aditya Media, Yogyakarta.

Nicholson. W. 2002. Mikroekonomi Intermediated dan Aplikasinya, EdisiKedelapan (Terjemahan), Erlangga, Jakarta.

Pahan, Iyung. 2008. Panduan Lengkap Kelapa Sawit. Penebar Swadaya, Jakarta.

Pahan, Iyung. 2010. Panduan Lengkap Kelapa Sawit Manajemen Agribisnis Dari HuluHingga Hilir. Penebar Swadaya. Jakarta

Pardamean, Maruli. 2008. Panduan Lengkap Pengelolaan Kebun Dan Pabrik KelapaSawit. Cetakan Pertama. PT.Agro Media Pustaka. Jakarta.

Soekartawi, 2005. Agribisnis Teori dan Aplikasinya, Raja Grafindo Persada Jakarta 2002. Analisis Usahatani. Penerbit Universitas Indonesia. Jakarta. Soehardjo \& Dahlan P. 1984. SendiSendi Pokok Ilmu Usahatani. UNHAS, Ujung Pandang.

Suratiyah, K. 2011. Ilmu Usahatani. Bogor: Penebar Swadaya. Jakarta.

Sutopo, 2012. Peranan Perkebunan Kelapa Sawit Rakyat Terhadap Penyerapan TenagaKerja Di Kabupaten Bengkalis. Fakultas Ekonomi Unri. Panam. http://repository.unri.ac.id/xmlui/bitstream/handle/123456789/2111/jurna 1\%20sutopo.pdf?sequence=1 Suwarto. 2010. Budidaya dan Pengolahan Kelapa Sawit. Kanisius: Yogyakarta UPTD Kecamatan Sungai Bahar 2017. Laporan Tahunan Kecamatan Sungai Bahar. Jambi 